\title{
Islam Aboge: Islam and Cultural Java Dialogue (A Study of Islam Aboge Communities In Ujungmanik, Cilacap, Central Java, Indonesia)
}

\author{
Abdurrahman Misno Bambang Prawiro ${ }^{1}$ \\ 1/slamic Boarding School YPIT Bogor \\ Email: abuaisy1979@yahoo.com
}

\begin{abstract}
Islam came to Java in which the state population has a form of cultural traditions and belief in the power of certain objects (dynamism), the strength of the spirit of the deceased (animism) and belief in the power of the animals (Totemism). This tradition has been passed from generation to generation; it is believed and practiced in daily life. So when Islam came, confidence and trust is dissolved into the Islamic culture. Therefore comes the so-called Islamic syncretism that is acculturation with Islamic tradition. Among the forms of local acculturation (Java) with Islam is a tradition embraced by the Muslim Aboge community in the village of Ujungmanik Kawunganten Cilacap district, Central Java province, Indonesia. These community traditions carry with spiced Javanese Islamic tradition, the Islamic came with local flavor. The specificity of this community are still use the models of Javanese Islamic calendar (calendar Aboge (Alip Rebo Wage)) to determine the beginning of Ramadan, Idhul Fithri and Idhul Adha. Because of the using of the calendar, so that the celebrations of Ramadhan, Idhul Fitri and Idhul Adha is always different to what has been set by the government. This article discusses Islam and Javanese acculturation on Aboge Islamic Community and the dating models they use. With the approach of phenomenology and interpretation of cultural studies in the frame of ethnography, it is expected to make clear this acculturation models.
\end{abstract}

Keywords: Acculturation Culture, Javanese Islam: Islam Aboge, calendar of Aboge (Alip Rebo Wage) and Local Wisdom

\section{A. INTRODUCTION}

There are three opinions about the theory of the entering of Islam to Indonesia, first opinion states that Islam entered Indonesia in the year $675 \mathrm{AD}$, this opinion is mentioned by TW Arnold in The Preaching of Islam A History of the Propagation of the Moslem Faith, he explained that Islam came from Arabia to Indonesia in the year $1 \mathrm{H}$ or in the Seventh Century AD (Hamka: 1996). The second opinion stated that Islam entered Indonesia in eleventh century AD. It is based on the discovery of the long the tomb in Leran Manyar, Gresik, it is the tomb of Fatimah Binti Maimoon and his entourage. On the tomb are inscriptions in Arabic script Riq'ah which dates to the year 475 $H$ (1082 AD) (Badri: 2001). While the third opinion states that Islam entered Indonesia in the thirteenth century AD. This opinion was mentioned by R.A Kern, C. Snouck and Schrieke (Sanusi: 1995).

Regardless of the number of these opinions, all historians agree that when Islam entered Indonesia, Indonesian society has a culture and customs of their own. The belief of Animism, dynamism and Totems is one evidence that Indonesian people have a culture that has been passed down from generation to generation. So when Islam entered Indonesia beliefs and cultures of Java is also entering into the traditions of Islam, so that there was an Islamic syncretism. Among the forms of assimilation (syncretism) between Islam and other local cultures is what has done by 
the Muslim Aboge community in the village Ujungmanik Kawunganten Cilacap district of Central Java. In some areas in the southern part of Java there are the Islam Community called Islam Aboge. Those communities began to spread from Wonosobo district, Purbalingga, Purwokerto, Banyumas and Cilacap (Joko: 2008). Among the characteristics of this community is that other community members cover them. Each will be a member must go through a special ritual (Baingat). This community is one of the Javanese Islam which in terms of Clifford Geertz called Islam Abangan (Geertz: 1981).

\section{B. METHODOLOGY}

\section{Methods Used}

This paper used comparative research methods. Comparative research is a method of research that is comparing. Here still the same object to different places more than one, or in a different time (Sugiyono, 2007, p.11).

\section{Type of Research}

Qualitative research is a study only describes the state of the object associated with the object under study are discussed in the study. This type of research is used to examine the condition of natural objects (as his opponent is an experiment), where the researcher is a key instrument (Sugiyono, 2006, p.9).

\section{RESULT AND DISCUSSION}

\section{Ujungmanik Village Glance}

Ujungmanik is the name of a village, which is etymologically derived from the two syllables of "ujung" and "manik". According to Mr. Sujarmin HP, an intellectual and village elders of Ujungmanik, Ujungmanik name is taken from the word "ujung" means an area that was at the end of existing settlements at that time (Geographically Ujungmanik village was located at the end of the villages located in the district Kawunganten Cilacap). While the name "Manik" is taken from the name of a princess named Nyi Roro Manik, the duke who died and was buried at the south end of the village, precisely in the Cikrewes (Interview Mr. Sujarmin HP: 2010). Nevertheless according to Mr Sujarmin HP, the arrival of Mbah Nurkasim and Mbah Haji Hussain is the next wave of the opening of the village Ujungmanik. Because the soldiers who did the invasion of Mataram are returning to the south because of the number of outbreaks of diseases such as malaria are still a lot going on at that time. So that was abandoned arable land and back into the woods, then just two founders of these villages came with his students.

Histories of Ujungmanik village on the version of the opening that are made by Mataram soldiers are closely related to the history of the district Cilacap. This version is based on the presence of the Tomb of Nyi Roro Manik regent at the southern end of the village. According to the story told by Mr. Sujarmin, that Nyi Roro Manik Patih was one of the nobles of Jogjakarta who fled due to attacks from forces of Padjadjaran. If we associate with a history of counties Cilacap it can be drawn a conclusion that Nyi Roro Manik Patih who was buried at the end of the village was the wife or family of Mataram soldiers assigned to secure the area Segara Anakan from the pirates and the attack of Pajajaran. As mentioned that the Mataram soldiers secure the area in Kampung laut, an area in the southwest part of the village Ujungmanik, another name of the village or the ocean is Bejagan or Pejagan, it means place just in case (Interview Mr. Sujarmin HP: 2010). 
Ujungmanik village is including to the District Kawunganten Cilacap, Central Java Province. Ujungmanik name refers to the area that is in the southern tip of the District Kawunganten. The eastern part bordering with Forest Teak plantations owned by private and Countryside with Bringkeng village of district Jeruk Legi. The southern part bordering Cigintung Village, District Kampung Laut and mangrove forests belong Perhutani. The western boundary adjacent to the village Grugu whiles the northern border with the Village District Kubangkangkung Kawunganten.

Geographically, the village is divided into two areas, in the west is a swamp that had mud and soil structure with the saltwater conditions from rivers that empty into the Segara Anakan (Indonesia Ocean) Cilacap, the western village is the hallmark of Village Ujungmanik so often called Parid because of its territory that has Parit trench (watery river salty). While the eastern part of the soil structure hills known as Nggunung. The village has seven (7) neighborhoods (RW) and sixty-six (66) neighborhoods (RT).

The majority of people are as laborers, peasants, it can be said laborers because most of the paddy fields in the village is owned by outsiders/the city especially Cilacap City. In the eastern region (Nggunung) population livelihood is as a producer of sugar and field cultivators. In the western region also has some of the population as fishermen. Religion professed by most of the people is Muslims, only a few families who are Christian and Catholic. Not many religious organizations that exist in the village besides Nahdhatul Ulama, it is certain that the shades of Islamic things in the village are traditional with a few variations of the congregation there. In between the majority Muslims in the village of Ujungmanik, there is a group of communities known as Islam Aboge. They are the descendants of Mbah Mad Darbiyyah, which are students from Mbah Nurkasim as one of the founders of the village. They inhabit some of RT and RW in the central part of the village. The number of them is concentrated in two RT, the RT 05 RW 05 and 06. Several other members spread in RT 03/04, RT 10/04, RT 08/05 and RT 07/05. The center of their worship was Masjid Baitus al-Salim and Mushala al-Nur.

\section{History and Origin of Islam Aboge}

The term of Islam Aboge refers to a community of generations of students Mbah Kyai Nurkasim. They are the first generation who opened the village Ujungmanik (trukah) in the north of the village. Mbah Nurkasim itself was one of the students who come from a boarding school in Pasir Luhur (Banyumas region). From this background so it is arise the term students of Pasir, and the term continues to grow up to be a reference to the Islam Aboge community.

From an interview with Mr. Abu Sujak there are obtained information that Islam Aboge Community in the village of Ujung Manik has been around since the beginning of the village of Ujung Manik. This was confirmed by the village elders, Mr. Madgaswin, said that the village was opened by two religious leaders are Mbah Nurkasim and Mbah Kyai Haji Hussain. Both leaders have followers who comprise their disciples or rather their students (interview Mr. Madgaswin: 2010). Mbah Haji Husain opened the village (trukah) west of the village, while Kyai Nurkasim the east. At first Islamic understanding between the two is not much different, however, when the Dutch government obliges and sets must follow a predetermined feast then began the difference in setting the feast day. Kyai Nurkasim Party insists on holding a calendar counting Aboge as imposing the beginning of Ramadan, Shawwal and Idhul Adha feast. While Haji Husain and his students chose to follow the provisions of the Dutch government.

But this opinion is difficult to accept because of differences in the institute can also be a matter of analysis. Islam Aboge lead congregations Syattiriyyah while villagers in general (Ujung Manik) are 
followers of this order Qadariyyah Naqsabandiyah. If we trace further the two congregations has its own mysticism (suluk) which different from each other. In the Ujungmanik between students of Mbah Nurkasim and Mbah Kyai Haji Hussain are two different camps, the community of followers Mbah Kyai Nurkasim now known as Islam of Abangan called Islam Aboge, while Mbah Haji Hussain's followers known as the Islamic Santri. (interview Mr. Madgaswin : 2010).

\section{The Religious Characteristics}

Islamic Community of Islam Aboge rested all forms of belief in Islamic beliefs of Ahlu Sunnah Wal Jama'ah. Judging from the terms of the Islamic faith, this community has been strengthening, especially in the field of Islamic faith, if compared with similar communities in otherr regions. According to Mr. Supandi as chairman (Kayim) community, they do not want to practice the things that lead to the polytheistic deeds like meditating to gain strength, to kill the tomb and did not do a special relationship with Jinn. "I reject when offered tuyul" he says enthusiastically. Such confidence is one of the forms of "evolution" that occurs in the body of this congregation. It may be that this is just a kind of self-defense, because of the interview with Mbah Madgaswin who said that their predecessors (Aboge Islamic community), especially the Kayim in this community is very strong with the mystical world. Particularly things related sciences superiority, which cannot be separated from the world of the Jinn. In this case there is contact with the supernatural that they are carrying out, for example, did penance at the grave with the intention of meeting with the spirits of the ancestors, (Interview Mr. Abu Sujak: 2010).

In the field of the congregation, the Islam Aboge Community follows Sheikh Siti Jenar with Suluk Syatariyyah. The congregation is growing rapidly in the "red areas" in Java, especially Central Java called Abangan Muslim majority. The congregation has become one of the special characters that exist on them. In general, a growing congregation in the village of Ujungmanik is the Order Naqsabandiyyah Qadiriyyah. So you can understand if the Islam Aboge community considered different to most of the religious leaders in Ujungmanik.

From the in-depth interview with one member of the Order of Syatariyyah congregation, mentioned that they have a model of mysticism by way of the dhikr by saying La ilaha illa Allah 99 times, then pressing the eyeball with both thumbs. With these things it is expected that our eyes closed and open our hearts, so it will be able to see things that are not visible, such as see prophets and even see the Almighty. Implicitly other members agreed this method just is not as imagined by the people,"Ya.... ora kaya kue carane" " Yes ... Not to work that way, "said Mr. Abu Kasan. So Islam Aboge community believe that Allah ta'ala be "presented" in certain moments, when certain dhikrremembrance. Not only can that, by performing certain rituals a man be one with God as a form of spiritual peak of their order.

In this ritual Muslim community Aboge still perform the obligatory prayers, fasting, haij and others. In the village itself the members of this community believe that prayer is an obligation, although in practice many of them do not do it. Moreover, the "Followers" who only followed moments of Islam Aboge holidays, they tend not to perform prayer and fasting Ramadan. There is the interesting part of this issue, when there are members of this community do not pray then by its leaders considered normal. From the analysis of this case because investigators learned the basic understanding of the weak against Islamic law, so assume that if they do not do shalat, it is understood. Not just a neighbor or someone else, even his own family when not praying considered something unusual in the sense that is not considered as a sin. 
From the interviews conducted with Kayem Supandi as community leaders, he stated that "Jorna bae lah... sue-sue tulih gelem sembahyang "' Let it wait until they want to pray ". Is it tolerance, propagation methods or superficial understanding of the syariat? Researchers are tending to state that this is because they lack the Shari'at's respective ideologies. Continuation of the study as a form of comparison is an interview with Kayem Mr. Hadi Paryono said that most of all members of this community have never studied in schools or in the formal education higher than elementary school (SD), even the president (Kayem) its own only studied religion to some kayem (religious teachers) are in fact local understanding of Islam is still lacking. (interview Mr. Kayem Hadi Paryono: 2010)

Actually, not only in the beginning but throughout the year in a period of one year and one tiger has its own formula. Dates Aboge is one of the calendar models that are static, meaning the default calendar that will not change because it's systematically obvious and raw. Although in its history there are some changes. The calendar is based on lunar Aboge established by Sultan Agung Hanyokrokusumo in Islamic Mataram kingdom in Surakarta. This calendar is the result of acculturation between Islamic and Javanese calendar.

Further this calendar models spread throughout the areas that became the Kingdom of Mataram, including area Pasir Luhur and other areas around the Banyumas and Cilacap. According the statement from Kuncen Mausoleum in Cikakak those elder dating models is spread by Eyang Mustolih to Cikakak Village, District Wangon, Banyumas, and Central Java since the year $1288 \mathrm{H}$. It is, as is believed by the Islamic community Blangkon in Banyumas and Cilacap. (Ridwan : 2008).

The existence of Islam and Javanese acculturation in dating Aboge seen from the names of months used. However, if seen from the number of days in a month and still attached to the term is clearly the Javanese culture, the term wage, kliwon, manis, paing and pon is pure from the Javanese calendar. Javanese cultural influence is still obvious, it can also be seen when the feast of Idhul Fitr and Idhul Adha falls on a Rebo Manis. According to them these days may not be used for highway spend a day, because it was not "good day" to spend a celebration, so the holiday falls on a day that will be replaced by the next day. This is caused by the opinion that the day Rebo Manis is as a kantonge dina (Parent day) so it should not be used as a feast or other fun activities, (interview Mr. Supeno as Kuncen: 2010)

According to Aboge calendar, a month consists of 30 days and 29 days. As counting in the Old Javanese society, the Aboge still using and counting in only eight (8) years to meet one cycle and repeated again from the beginning of the year names: Alip, Eehe, Jim Awwal, Jee, Dzal, Bee, Wawu, and Jim Akhir. In the calculation of Islam in Java (dating Aboge) a years is beginning with the Year Alip who has twelve months with the following formulas:

\begin{tabular}{|c|c|c|c|c|}
\hline No. & Theory & Month & Days & Pasaran \\
\hline 1. & Ram Ji Ji & Muharram & Rebo & Wage \\
\hline 2. & Par Lu Ji & Sapar & Jemu'ah & Wage \\
\hline 3. & Lud Pat Ma & Mulud & Setu & Pon \\
\hline 4. & Ngu Khir Nem Ma & Robingul Akhir & Senen & Pon \\
\hline 5. & Dzu Wal Tu Pat & Jumaddil Awwal & Selasa & Pahing \\
\hline 6. & Dzi Kir Ro Pat & Jumaddil Akhir & Kemis & Pahing \\
\hline 7. & Jab Lu L & Rajab & Jemu'ah & Manis/legi \\
\hline 8. & Wah Ma Lu & Ruwah & Ahad & Manis/legi \\
\hline 9. & Sa Nem Ro & Puasa & Senen & Kliwon \\
\hline 10. & Wal Ji Ro & Syawal & Rebo & Kliwon \\
\hline 11. & Dah Ro Ji & Dzulqa'adah & Kemis & Wage \\
\hline 12. & Jah Pat Ji & Dzulhijjah & Setu & Wage \\
\hline
\end{tabular}


How to read this table is the beginning from the year Alip Muharram that are abbreviated to "ram" which falls on Wednesday (ji = Siji, a name for the first day in the Javanese calendar), and wage (the name of the first pasaran in the Javanese calendar), because it means ram sacred, $j i j i$ means next Wednesday and mean wage. From this table we can know the day and the pasaran's early days in each month of the year Alip. For example for the month of Shawwal for simultaneously determining the feast, then in Alip will fall on Wednesday Kliwon, this because the formula is Waljiro, Shawwal Siji Loro, in Sawal fell on Wednesday, the first day (Siji = ji) and kliwon is the second pasaran (loro = ro). To set the early of Ramadan in the year Alip is using the formula of Sanemro. Sa mean fasting month or Ramadan, Nem is enem (six) as the sixth day in the Javanese calendar and Ro (loro $=\mathrm{ro}$ ) is the second days in the Islamic Javanese calendar. These formulas apply also to the determination of Idhul Adha feast and the other months. This is the cause of the Muslim community Aboge have to know when the beginning of Ramadan, the feast Idhul Fitr' and Idhul Adha. In the following years will be adjusted and continue with the previous days. (interview Mr. Pidin : 2010). Those days are believed to be the worse fateful day of abstinence starting a job or travel. There is also a belief in the quality of a day in a month. Today the trust in time, lucky days and bad by members of the public, especially people Ujungmanik still adhered to, although the fact that only apply to certain areas of life such as start plantation (rice plantation), marriage, long trips, fishing and other traditional ceremonies.

\section{Islam Aboge: Islam and Java Cultural Dialogue}

As the Java community at large, the Muslim Aboge community performs various religious rites on the basis of belief in their ancestors. Their Confidence have embraced for years even decades, it is difficult for them to leave. It is widely understood by the preachers and the preachers who spread Islam in the region, we conducted a variety of ways to make Islam acceptable to the indigenous population although some points deviated from Islam. Some forms of acculturation found in the Islam Aboge community is ritual which is a collaboration between the culture and beliefs previously seasoned with Islamic values, among acculturation are:

\section{a. Selametan of Pregnancy}

Selametan is performed on a woman who is pregnant and reaches gestational age four months and seven months gestation. The hallmark of this selametan was made "lepet", i.e cooked glutinous rice and coconut leaves inserted into the wound so as to form a unique traditional food. This tradition has historically come from cultures worship the gods under god Yin and Yang. Still related to pregnancy a pregnant woman then she should hang scissors or a small knife so that the unborn babies are protected from evil spirits. Belief in confounding the baby still in the womb is came from the beliefs of animism and dynamism. In addition there is also the uba rampe such offerings and giving Uthuk (chicks) to the midwife. Islamic values in selametan is holding siege that invite the neighbors for a bite to eat in the evening. By presenting a kayem so many prayers, tahlil, tahmid and recited the rosary as a form of gratitude and supplication to God.

\section{b. Baby Birth Ritual}

The birth of a baby is a moment of particular concern in Javanese culture. When a woman gave birth, the placenta called sadulur pancer immediately put into a green coconut or an earthenware jug. Furthermore, the placenta is placed near the door so that the elder brother of the baby to be able to freely leave the house. The Placenta is given the pulp and some types of flowers. They believe that the brother of the newborns still in the vicinity. The Model of placenta treatment carried out by the Islamic Aboge community and rituals associated with the birth of a baby is a pure as a 
culture of Java. Forms of acculturation in this ritual are the baby's hair cut on the seventh day. This procession is certainly not known for any aqiqah, then the new generation known this as aqiqah. However, the determination of the seventh day and the name is one of the traditions of Islam. So as the procession ngupati and Keba, in its own naming ritual performed siege by inviting the neighbors for a bite to eat together and pray for the baby name.

\section{c. Circumcision Celebration}

Circumcision is Islamic tradition that has been widely accepted by the Java community. Before the advent of Islam, the Java community does not recognize the existence of circumcision, the Islamic tradition blend with tradition by creating the Java ritual circumcision for boys. Culture of circumcision for current child becomes a qualified party with Javanese culture. Implementation of the Islamic Aboge community circumcision performed when a boy has entered legal age, usually between the ages of 10-14 years. This celebration takes the form of celebration is encirclement by inviting the neighbors to eat together and say the rosary, and tahlil tahmid. If the child's parents were prominent then the bride circumcision increased the horse with Arabic makeup with clothing such as a long white robe and turban. Circumcision bride paraded around the village by riding a horse or wagon. They said it was done to please the child. For boys the only one in the family then the process must be carried out certain ritual circumcision with nanggap (hold) puppet show, (interview Mrs. Muntasiyah). But this tradition is now becoming obsolete due to the high cost of hiring shadow puppets. In some celebrations circumcision is often done khatam Al-Quran event for children who are circumcised. The event itself was very festive celebration of circumcision as wedding celebrations. In this celebration there was a party leader who chaired the event in addition to providing a variety of specific offerings.

\section{d. Wedding Celebration}

Wedding celebration was a great moment that characterizes Javanese culture. Although in some cultures was also carried out but the values contained in Javanese wedding ceremony is very complex and contains many of acculturation. Islamic culture, Java and any other faith. Acculturation that occurs in the celebration of marriage is a valid marriage contract in Islam and the wedding procession that followed the Javanese culture. Among the forms of acculturation are: unification of the procession and the wedding ceremony held in a single package, so as if not valid if the wedding is only performed in front of the Office of Religious Affairs (KUA). Unification reflects that between Islam and Javanese culture is not any conflict because it can be implemented in tandem, according to their opinion.

\section{e. Ritual of Death (Tahlilan)}

Furthermore, Islam and Javanese acculturation that are still carried out by the Islamic Aboge Community is a celebration (selametan) or tahlilan after a person's death. Funeral ceremony conducted at the village Ujungmanik is started from day 3,7,40,100 and a year or khaul after death. In the Islamic tradition that developed in the Middle East and other regions there are not known this ritual (tahlilan). It is also similar in other areas such as Sumatra, Java and others. This shows that this is a genuine rite of Javanese culture. If we trace the history of ritual tahlilan, then we will get that ritual is derived from the belief God Yang from China, (Merzedeq : 2002). Where this confidence also spread to areas of Southeast Asia, including to Java. So after all this time it developed this faith as an integral part of Javanese culture. It is strengthened with the arrival of Hinduism and Buddhism that strengthen this ritual. (Sholikhin : 2010). So when Islam came to Java, the culture is so strong so that it is impossible to eliminate. So the preacher just pinning 
values of Islam into the culture of death rituals. Naming itself becomes "tahlilan" which literally means reading the sentence tahlil la ilaha illallah.

\section{f. The Worship of Grave}

Respect for ancestors is part of the Javanese tradition that cannot be separated in daily life. It is not only based on the obligation to respect to the elder people, but more than that is the belief that the ancestors can provide assistance to their grandchildren. This can happen either when he was live or had died. Proportional to the rituals after death, respect for the deceased ancestors is a tradition that cannot be disturbed again. Although they have embraced Islam but, understanding that the spirits of the dead can come back to his place and give relief to his descendants. Therefore the construction of various tombs and graves is one manifestation of respect for the dead. In the Muslim Aboge community that are characterized by respect for their ancestors, especially those that have spread Islam Aboge and bequeath to them. Based on Kayem Supandi this community are always carrying out a pilgrimage to the tomb of Mbah Nurkasim at Cikakak village, Wangon as a form of homage to the ancestors who had opened the village Ujungmanik and spread Islam in the region, (interview Mr. Supandi: 2010)

The tomb of the ancestors on communities Ujungamanik often called Petilasan known as Panembahan. From the observation there are about ten Panembahan in this village. Panembahan is a grave thought to have certain powers because tomb owners are honorable people, powerful or respected. From some existing Panembahan, which is still preserved is Panembahan Cipacul, Panembahan Langlang Alun, Panembahan Nusa Cething, Panembahan Baya Ragas, Panembahan Polosuro Polosari, Jatikusumo, Jati Marong and others. Discusses about Panembahan is cannot separated from the incense and offerings. In the community of Islam Aboge burning incense and offering is very important. Moreover, at the time of pilgrimage grave or a particular ritual. Offerings and burning incense (incense) is performed at certain moments, especially during ceremonies such as weddings, circumcisions and others. The form itself diverse offerings, if Friday night placed red and white pulp and water next to the house. While the offerings of a single wedding always cooked rooster, red and white pulp and a few jajanan pasar. Do not forget the burnt incense, cigarettes, coffee, green tea and coconut. The tradition of pilgrimage grave, glorifying the deeds of the ancestors and pray for deceased are Islamic tradition, but when met with Javanese culture is created acculturation, making pilgrimages tomb interpreted by the Javanese will be different from that understood the grave pilgrimage of Muslims in other areas. Similarly, respect for ancestors in Islam is emphasized, but when it comes in the form of begging the spirits of the ancestors in order to provide relief to people who are still alive then it is not in accordance with Islamic values.

\section{g. Idhul Fitri, Idhul Adha, and Salambekti}

Celebrations of Idhul Fitri and Idhul Adha carried out by the Islamic Aboge community are different from Muslims in general. In Idhul Fitri celebration first ritual was performed by making dian (light bulbs) of five or seven pieces in a large bamboo pole. Bamboo is made horizontal closed at both ends to hold the soil in order not to spill oil. Furthermore, the incandescent lamp is placed in front of the house, some of the offerings of flowers and red and white pulp is placed in a small dish and banana leaves, and placed under the fluorescent lights. Furthermore, after maghrib takbeer echoed arrived together in mosques and prayer room. Repercussion takbeer was originally performed by children and youths, while the father depositing tithes to kayem as amil zakat. In the Muslim Aboge community, collecting zakat done in house chairman (kayem) so in the night the kayem's residence was very crowded. Based on the tradition, after the father give zakat fitrah they 
did not go home, but they enjoyed the dishes provided by these kayem. Usually dishes such as muddy (goat meat dishes, chicken or other meats).

In the morning they flock to the mosque Baitus Salim, repercussion takbir still sounds to pray 'Idh implemented. As other Islamic community, the Muslim Aboge community when leaving the mosque also brings the food prepared for the event in the mosque siege after Idhul Fitri prayers finished. Idhul Fitri prayers held this community as the Muslims in general, after the completion of the next ritual is salambekti. Salambekti mutually apologize for any falseness that may have been done before. The process of Salambekti begins with the sound of praise and voiced Shalawatan together. Furthermore Kayem standing right next to the mihrab and followed by the pini sepuh (parents), they are shaking hands in turn, was followed by the general public who greet one another.

The entire jama'ah Idhul Fitri prayers greet one another and form a circle in the mosque, if it will not fit in the courtyard of the mosque and continued on the highway. Although members of the Islamic Aboge Community are only about 100 families but when 'Id arrives surrounding communities who are not even this community joined in this salambeti. This has resulted in the line of greeting-shake is booming up to the highway. All men and women, old and young all shake hands with each other. "Siki wektune nggo njaluk pangapura" (Now it's time to apologize) said one of the pilgrims. Although they were shaking hands at the mosque, but the event of salambeti still ongoing. They toured the house-to house and begged for forgiveness from the residents. Usually houses visited were the home of the parents and the elder ones, such kayem, village chiefs, clerics and others. When citizens do salambeti the jama'ah Kayem Supandi and some male members of the Islamic Aboge community remain in the mosque to perform the next ritual named Babaran, i.e do salambekti more specialized and humility that starts from the elders and kayem. The procession is as follows: Kayim as chairman figure of Islam Aboge community sitting and attended by other religious leaders. By way of sitting amid prostrate, Sungkeman began. One by one the snaking who the youngest do Sungkeman tradition. "The point is that people ask forgiveness to the elderly. Since the day this is the perfect time to return to the fitrah" (Interview Mr. Supardan).

Once the ritual salambekti is completed next Mr. Kayem Supandi lead salvation prayer that all members of the jama'ah and the Muslims in general have always been in the shadow of Gusti Allah. Do not forget the prayer tucked tawasul the previous pious people, especially the founders of the village and especially Ujungmanik ancestors who were in line Islam Aboge. Finally rituals serve cone and covered with rice that comes with side dishes such as chicken, vegetable fried noodles and others. Although the food was tasty enough, but most of jama'ah were present only eat a little bit, the rest is taken home as brekat (Food after salvation). Speech forgiveness was largely implemented in the language of krama inggil. The word is as follows: "Allohumma shali 'ala sayidina Muhammad wa 'ala ali sayidina Muhammad, Pak/bu Kulo ngatureken sedoyo lepat kulo, kulo tiang enem kathak lepate nyuwun ngapunten kali bapakae. (Mr. I Mrs. I apologize for my mistake, I was young a lot of mistakes so I apologize to the father I mother). So those who received letters were also answered by Javanese krama or sometimes Javanese ngoko: "Allohumma shali 'ala sayidina Muhammad wa 'ala ali sayidina Muhammad, Ya pada-pada, aku wong tua mbok ana lupute ya njaluk pangapura"(Yes you're welcome, I as a parent if there are mistakes also apologize). Although most of the residents Aboge not fast but at this feast all happy, they held the stage on several occasions like ebeg (lumping horse) as a form of entertainment for the community. 


\section{h. The calendar Alip Rebo Wage (Aboge)}

The combine between Islam and Javanese cultural that become the characteristic of this community is the use Aboge calendar. This calendar is based on the calculation of days, months and years have been compiled systematically. At first the preparation of this calendar system is on the order of Sultan Agung Hanyakrakusuma as the supreme holder of Mataram kingdom on that time. With the passage of time of the modification and a few adjustments, thus dating the model is slightly different to what has been established initially by the Sultan. The process of setting the calendar is based on the needs of Javanese Muslims to any certainty in determining the time of festivals, such as Idhul Fitri and Idhul Adha, and also the beginning of Ramadan. Further models of this calendar spread throughout Mataram area included Banyumas and Cilacap. This calendar system entered Banyumas and Cilacap brought by Eyang Mustolih, precisely in the Village Cikakak, District Wangon, Banyumas regency, Central Java. As mentioned by the Savior Cemetery in the Village Cikakak that the calendar model of has been used in this village since the year $1288 \mathrm{H}$. It is characterized by the establishment of mosques Saka Tunggal in the region that is still sacred by Islamists Aboge.

From interviews with Mr. Madgaswin as Ujungmanik village elders institutes that the congregation of Islam Aboge is as a continuation of the congregation of Shaykh Siti Jenar propagated by a scholar named Raden Rasid Sayid Kuning dari Pajang. But this opinion is disputed by Ustadz Amiruddin Kadar who is stating that if they followed his order Shaykh Siti Jenar was good, their order is different and incompatible with Sheikh Siti Jenar's suluk. (interview Mr. Amirudin Kadar : 2010) In spite of these disagreements Pak Warsidi themselves as members of the Islamic Aboge community said that the congregation was being operated close to the model of Sheikh Siti Jenar.

As mentioned, the calendar used by the Community of Islam Aboge is a form of acculturation between the Javanese calendar and lunar Islamic Hijiyah. Of the names used, it is obvious that it comes from the months of the Hijriyah. However, if seen from the number of days in a month and still attached to the term to the term 'pasaran' today is definitely Javanese culture? The influence of Javanese is still noticeable, it can be seen when the feast of Idhul Fitri and Idhul Adha falls on Rebo Manis, according to them the day was not a good day to spend a celebration, and so the holiday falls on a day that will be replaced by the next day. Although in practice Rebo Manis never exist in the calendar system. In determining the initial entry of the year and the beginning of the month, the calendar is based on a formula Aboge which stands for Alip Rebo Wage, which is Alip become an earlier year and should fall on a Wednesday and pasaran wage. In every year there are twelve months in accordance with the falling termed early day. For example, in Alip: So the first month beginning with the month abbreviated sacred ram, on Wednesday in pasaran termed wage is $j i$ and $j i$ be termed ramjiji. This is valid for the entire month those as many as twelve months. In the eight years that have different names, Aboge calendar has twelve months may be abbreviated in accordance with the final piece syllable, the following terms are used: 1 . Muharam $=$ ram. 2 . Sapar $=$ par. 3. Mulud $=$ lud. 4. Robingul akhir $=$ Ngu khir. 5. Jumadil Awwal $=$ Ju wal. 6 . Jumadil Akhir $=$ Ju khir. 7. Rajab $=$ Jab. 8. Ruwah $=$ Wah. 9. Puasa $=$ Sa. 10. Sawal $=$ Wal. 11. Dzulqangidah $=$ Dah 12. Dzulhijjah $=$ Jah

Furthermore, the order of the day and the pasaran sorted according to the early day, as the following table:

\begin{tabular}{|c|c|c|}
\hline No & Days & Terms \\
\hline 1 & Rebo & Ji \\
\hline 2 & Kemis & Ro \\
\hline
\end{tabular}

\begin{tabular}{|c|c|c|}
\hline No & Days & Terms \\
\hline 1 & Wage & $\mathrm{Ji}$ \\
\hline 2 & Kliwon & Ro \\
\hline
\end{tabular}

\begin{tabular}{|c|c|c|}
\hline No & Days & Terms \\
\hline 1 & Siji & Ji \\
\hline 2 & Loro & Ro \\
\hline
\end{tabular}




\begin{tabular}{|c|c|c|}
\hline 3 & Jemuah & Lu \\
\hline 4 & Setu & Pat \\
\hline 5 & Ahad & $\mathrm{Ma}$ \\
\hline 6 & Senen & $\mathrm{Nem}$ \\
\hline 7 & Selasa & $\mathrm{Tu}$ \\
\hline
\end{tabular}

\begin{tabular}{|c|c|c|}
\hline 3 & Manis & Lu \\
\hline 4 & Paing & Pat \\
\hline 5 & Pon & $\mathrm{Ma}$ \\
\hline & & \\
\hline & & \\
\hline
\end{tabular}

\begin{tabular}{|c|c|c|}
\hline 3 & Telu & Lu \\
\hline 4 & Papat & Pat \\
\hline 5 & Lima & $\mathrm{Ma}$ \\
\hline 6 & Enem & Nem \\
\hline 7 & Pitu & Tu \\
\hline
\end{tabular}

The influence of Islamic tradition in this calendar system is a term for the names of the months. Originally the first month in the Javanese tradition is Suro, The calendar Aboge does not use the term Suro, but they use the term Muharam. Similarly, other months, just months Mulud and Fasting affected Javanese tradition. In Hijriyah lunar month of fasting called Ramadan, likewise called Mulud Jumada al-Awwal. Although in practice these two names are also sometimes used. Within a month, the number of days in the calendar Aboge system consisting of 30 and 29 days. As counting in the ancient Javanese people, the Aboge also still using and counting in only eight (8) years to meet one cycle and repeated again from the beginning of the year names: Alif, Eehe, Jim Awwal, Jee, Dal, Bee, Wawu, and Jim Akhir. In calculating this year starts with Alif year has twelve months with the following formulas:

\begin{tabular}{|c|l|l|l|l|}
\hline No. & Abbreviation & Month & Days & Pasaran \\
\hline 1 & Ramjiji & Muharam & Rebo & Wage \\
\hline 2 & Parluji & Sapar & Jemuah & Wage \\
\hline 3 & Ludpatma & Mulud & Setu & Pon \\
\hline 4 & Ngukhirnemma & Robingul Akhir & Senen & Pon \\
\hline 5 & Diwaltupa & Jumadil Awal & Selasa & Paing \\
\hline 6 & Dikhirropat & Jumadil Akhir & Kemis & Paing \\
\hline 7 & Jablulu & Rajab & Jemuah & Manis \\
\hline 8 & Wahmalu & Ruwah & Ahad & Manis \\
\hline 9 & Sanemro & Puasa & Senen & Kliwon \\
\hline 10 & Waljiro & Sawal & Rebo & Kliwon \\
\hline 11 & Dahroji & Dzulqoidah & Kemis & Wage \\
\hline 12 & Jahpatji & Dzulhijjah & Setu & Wage \\
\hline
\end{tabular}

Of each month we will know the beginning of the month, for example, for the month of as well as determination of the holiday, then in Alif will fall on Rebo Kliwon. Similarly to set Idhul Fithri and fasting. In the following years will be adjusted to the previous days, (interview Mr. Warsidi). Formulas that are applied in the following years are as follows: For the year Eehe the beginning of the month and the beginning of the year to continue the previous year, can be seen in the following table:

\begin{tabular}{|c|c|c|c|c|}
\hline No & Abbreviation & Month & Days & Pasaran \\
\hline 1 & Rammama & Muharam & Ahad & Pon \\
\hline 2 & Partuma & Sapar & Selasa & Pon \\
\hline 3 & Ludjipat & Mulud & Rebo & Paing \\
\hline 4 & Ngukhirlupat & Robingul Akhir & Jemuah & Paing \\
\hline 5 & Diwalpatlu & Jumadil Awal & Setu & Manis \\
\hline 6 & Dikhirpatlu & Jumadil Akhir & Setu & Manis \\
\hline 7 & Jabturo & Rajab & Selasa & Kliwon \\
\hline 8 & Wahroro & Ruwah & Kemis & Kliwon \\
\hline 9 & Saluji & Puasa & Jemuah & Wage \\
\hline 10 & Walmaji & Sawal & Ahad & Wage \\
\hline 11 & Dahnemma & Dzulqoidah & Senen & Pon \\
\hline 12 & Jahjima & Dzulhijjah & Rebo & Pon \\
\hline
\end{tabular}


These terms are used in a beginning of a new month, it is used to facilitate the recall. In the following years will continue to complete the final year of the end of year Jim. With this system, the establishment of Ramadan, Idhul Fitri and Idhul Adha in Aboge calendar is very easy, especially with the development of computer technology, so it can be easily in defining important dates in Islam. For instance, the year 2010 is the year of $D a l$, so the beginning of Ramadan, Idhul Fitri and Idhul Adha will easily known. Here is the table for Year Dal:

\begin{tabular}{|c|c|c|c|c|}
\hline No. & Abbreviation & Month & Days & Pasaran \\
\hline 1 & Rampatlu & Muharam & Setu & Manis \\
\hline 2 & Parnemlu & Sapar & Senen & Manis \\
\hline 3 & Ludturo & Mulud & Selasa & Kliwon \\
\hline 4 & Ngukhirroro & Robingul Akhir & Kemis & Kliwon \\
\hline 5 & Diwalluji & Jumadil Awal & Jemuah & Wage \\
\hline 6 & Dikhirluji & Jumadil Akhir & Jemuah & Wage \\
\hline 7 & Jabnemma & Rajab & Senen & Pon \\
\hline 8 & Wahjima & Ruwah & Rebo & Pon \\
\hline 9 & Saropat & Puasa & Kemis & Paing \\
\hline 10 & Walpatpat & Sawal & Setu & Paing \\
\hline 11 & Dahlulu & Dzulqoidah & Jemuah & Manis \\
\hline 12 & Jahtulu & Dzulhijjah & Selasa & Manis \\
\hline
\end{tabular}

From the table it can be seen that the beginning of Ramadan for 2010 fall in term Saroma that $S a$ is Fasting, Ro is the second day of the Loro (Thursday) and Pat = papat is the pasaran into four paing. Basically Aboge calendar models are static; it means that no changes have occurred to the date. But according to Mr Sujarmin HP the Aboge calendar has actually changed as much as two times, he simply stated that changes to the current is not possible due to lack of system of government has the right to change it.

Change is a variation of this calendar system, if the Muslim Aboge community is known with thick accent called Islam ngapak from the south, then to the environment with the Java language bandek there will be some differences. According to Ranggawarsita, to determine the first Sura in subsequent years so the formulation is as follows. Ekatpon, meaning in Ehe falls on akat night (Sunday) Pon. Walmahpon year Jimawal falls on Jemuah night (Friday) Pon. Jesoing in Je year Pahing fell on Tuesday night. Daltugi, in Dal year fall Legi Saturday night. Bemisgi, in year Be fell on Legi Thursday night. Wunenpon in Wawu year falls on Monday evening Pon. Kirmahge in year Jimakir as will now be happening, fall Jemuah 1 Sura at night (Friday) Wage.

Another variation suggested by Koesmin, who argued that the determination of the beginning of each calendar year Aboge can be done with the method of determining the date of each subsequent months, by basing the initial calculations Rojiji. That is the month of Suro Siji-Siji (one on one). The one here shows the order of calculation of the guideline figure for next Wednesday and one for the pasaran Wage. For months Sapar, named Parluji. That is, only months Sapar first date falls on a count telu Siji (Friday Wage). Bulan Mulut wear Mupatmo (papat five) fell Saturday Pon. Bakdomulut use Banemo (enem lima) fell Monday Pon. Jumadiawal with the guidelines Walpipat (pitu papat) fell Tuesday Pahing.

Then Jumadilakir counts Kiropat (loro papat) on Pahing Thursday. Rejeb wear Jeblulu (telu telu) on Friday Legi. Meanwhile Ruwah with Wahmolu (limo telu) on Sunday Legi. For Poso, Ponemro (enem loro) Sunday Kliwon. Sawal, Sajiro (Siji loro) Wednesday Kliwon. While Dulkaidah use Dahroji (loro Siji) Thursday Wage, and Besar with a count Sarpatji (papat Siji) Saturday Wage. For clarity, the order of the day, consisting of one to seven Wednesday, Thursday, Friday, Saturday, Sunday, Monday, and Tuesday. Then the sequence of pasaran, one to five is Wage, Kliwon, Legi, 
Pahing, and Pon. There is not much different models in Aboge calendar that developed in several areas in Java, which is used as a model. The calendar Aboge guidelines are as follows: 1. In the year Alip beginning with Rebo wage. 2. In the year Eehe beginning with Ahad Pon 3. In the year Jim Awwal beginning with Jemuah Pon. 4. In the year Jeel beginning with Selasa Paing. 5. In the year Dal beginning with Setu legi. 6. In the year Bee beginning with Kemis Legi. 7. In the year Wawu beginning with Senen Kliwon. 8. In the years Jim Akhir beginning with Jemuah Wage. In detail can be seen in the following table:

\begin{tabular}{|c|c|c|c|c|c|c|}
\hline \multirow{2}{*}{ No. } & \multirow{2}{*}{ Years } & \multicolumn{2}{|c|}{ Early days } & \multicolumn{2}{c|}{ End of Days } & \\
\cline { 3 - 7 } & & Days & Pasaran & Days & Pasaran & \\
\hline 1 & Alip & Rebo & Wage & Rebo & Kliwon & 2006 \\
\hline 2 & Eehe & Ahad & Pon & Ahad & Wage & 2007 \\
\hline 3 & Jim Awwal & Jemuah & Pon & Jemuah & Wage & 2008 \\
\hline 4 & Jee & Selasa & Paing & Selasa & Pon & 2009 \\
\hline 5 & Dal & Setu & Legi & Setu & Paing & 2010 \\
\hline 6 & Bee & Kemis & Legi & Kemis & Paing & 2011 \\
\hline 7 & Wawu & Senen & Kliwon & Senen & Legi & 2012 \\
\hline 8 & Jim Akhir & Jemuah & Wage & Jemuah & Kliwon & 2013 \\
\hline
\end{tabular}

If the end of the year Jim had ended then started again from Alif year with the same formula, then here will never change. The beginning of the month then it just continued from previous months, for example in year Alif began on Rebo Wage and ends on Rebo Kliwon in Eehe year. It will continue from the day i.e Ahad pon, and so on. The use of abbreviations that is taken from the beginning of the word is very easy to memorize the names of the month. In addition, because of its static it can easily be learned and memorized. For example, for years Alip, here is a day at the beginning of the month and abbreviations:

\begin{tabular}{|c|c|c|c|c|}
\hline No. & Theory & Months & Days & Pasaran \\
\hline 1 & Ram Ji Ji & Muharam & Rebo & Wage \\
\hline 2 & Par Lu Ji & Sapar & Jemuah & Wage \\
\hline 3 & Lud Pat Ma & Mulud & Setu & Pon \\
\hline 4 & Ngu Khir Nem Ma & Robingul Akhir & Senen & Pon \\
\hline 5 & Dzu Wal Tu Pat & Jumadil Awwal & Selasa & Pahing \\
\hline 6 & Dzi Khir Ro Pat & Jumadzil Akhir & Kemis & Pahing \\
\hline 7 & Jab Lu Lu & Rajab & Jemuah & Manis/legi \\
\hline 8 & Wah Ma Lu & Ruwah & Ahad & Manis/legi \\
\hline 9 & Sa Nem Ro & Puasa & Senen & Kliwon \\
\hline 10 & Wal Ji Ro & Syawal & Rebo & Kliwon \\
\hline 11 & Dah Ro Ji & Dzulqa'dah & Kemis & Wage \\
\hline 12 & Jah Pat Ji & Dzulhijjah & Setu & Wage \\
\hline
\end{tabular}

With these details became clear that Aboge calendar models which the Islamic Aboge Community in Ujungmanik guides. For more details can be found in the appendix of this study. As mentioned earlier that basically Aboge dating system has undergone some changes (dinasakh) which should have been Asapon, because in Java already had three change in years, that are anjumgi (Alip year starting on jemu'ah Legi: is valid until the year 1674 ), then Akawon (Alip year starting on Kemis Kliwon: this effect from the year 1675 until the year 1748). Then Aboge (Alip year starting on Rebo Wage: this effect from the year 1749 until the year 1866). 


\section{CONCLUSION}

The Acculturation of Islam and Javanese culture in Islamic Aboge communities consists of rituals associated with pregnancy, birth, circumcision, marriage, death, and festivals. The breakdown is as follows:

1. Pregnancy Ritual consists of: the ritual ngupati and seven months of pregnancy. After Childbirth Ritual: the form of a procession of care afterbirth (placenta) baby and the name on the seventh day. Celebrations of circumcision for boys in a siege or a family party.

2. Wedding celebration (walimah) and matters related thereto. Tahlilan, the tahlil reading and prayer held on the third day, seventh day, forty days, one hundred days and one year after the person's death.

3. Idhul Fithri and Idhul Adha festivals (eating together) and Salambekti after prayers Idhul Fitr and Idhul Adha.

The characteristics which become the special characteristic of the calendar of Islamic Aboge community is the use as a guide in determining the beginning of Ramadan, the feast Idhul Fitri and Idhul Adha. This calendar is based on the calendar of Islam Javanese by Sultan Agung in the Kingdom of Islamic Mataram. The word itself is an acronym of Aboge Rebo Wage Alip the guidelines that the first year in this system is Alip year, which falls on Rebo wage. Since this calendar is static there is no change in determining the feasts. This calendar system is as the model of reckoning 'urfi, i.e on the basis of traditional cultural calendar. Because the calendar of Islam Aboge community is differ with Muslims in general, especially with regard to determining the beginning of Ramadan, the feast Idhul Fitri and Idhul Adha.

The concept of religious belief is clearly reflected in their patterns of belief in the existence of man in this life. "Menungsa iku kudu eling lan waspodo, ayo dhewek urip rukun bareng-bareng aja pada nyalahna wong liya" (people living in the world should always remember the Creator and always vigilant, let us live peacefully together and not blame each other). The concept is based on the pattern of living in harmony and mutual respect with other groups. Religious beliefs are positioned as the right of every human being of a personal nature. The spirit of coexistence has been institutionalized. Mutual respect is applied in the form of allowing Muslims who do not pray, do not fast and do not run other Islamic Shari'a. They think that prayer is only a means, if there are other means of achieving the goal of mind to God then it can be done, even if the person does not pray. Respect for the ancestors of this community embodied in the form of a pilgrimage to the tomb of Mbah Kyai Nurkasim Cikakak, Wangon Banyumas district. The pilgrimage is done every month Sadran (Sha'ban). This month several similar societies elsewhere gathered at the tomb to make a pilgrimage and ritual baingat. It can be said that they are doing the ritual shaft centered on the tomb. 


\section{References}

A.D. Elmarzdedeq. Parasit Aqidah, Bandung: Yayasan Ibnu Ruman.

Al-Taftazani., al-Ghanimi, Abul Wafa. (1997). Sufi dari Zaman Ke Zaman. Bandung: Pustaka.

Dawanas N, Djoni dan Purwanto. (1994). Penentuan Awal Bulan Ramadhan dan Syawal-Seminar Ilmu Falak di Planetarium dan Observatorium. Jakarta.

Denny, Frederick Mathewson. (1996). "Ritus Penguburan" dalam John L. Esposito (ed), The Oxford Encyclopedia of the Modern Islamic World. New York: Oxford University Press.

Doyodipuro, Ki Hudoyo. (2002). Horoskop Jawa Misteri Pranata Mangsa. Semarang: Dahara Prize.

Elliade, Mircea. (1996). "Hakikat yang Sakral" dalam Daniel L. Pals, Seven Theories of Religion, New York: Oxford University Press.

Geertz, Clifford. (1981). Abangan, Santri, Priyayi dalam Masyarakat Jawa, terj. Aswab Mahasin, Jakarta: PT. Dunia Pustaka Jaya.

Hamka. (1996). Perbendaharaan Lama. Jakarta : Pustaka Panjimas.

Herusatoto, Budiono. (2008). Banyumas: Sejarah, Budaya, Bahasa dan Watak. Yogyakarta: LKiS.

John R. Bowen. (1996). "Agama Rakyat di Asia Tenggara" dalam sub "Penyembuhan" pada John L. Esposito (ed), The Oxford Enxyclopedia of the Modern Islamic World. New York: Oxford University Press.

Joko Sulistyo. (2008). Analisis Hukum Islam Tentang Prinsip Penanggalan Aboge Di Kelurahan Mudal Kecamatan Mojotengah Kabupaten Wonosobo. Tesis Fakultas Syariah IAIN Walisongo,.

Koentjaraningrat. (2002). Pengantar Antropologi Budaya. Jakarta: Rineka Cipta cet. VIII.

Madjid, Nurcholis. (2000). Islam Agama Peradaban. Jakarta: Paramadina.

MC, Wahyana Giri. (2010). Sajen dan Ritual Orang Jawa. Yogyakarta: Penerbit Narasi.

Moleong, Lexi J. (2006). Metodologi Penelitian Kualitatif. Bandung : Remaja Rosda Karya.

Nasr, Sayyed Hossein. (1994). Islam Tradisi di Tengah Kancah Dunia Modern. Bandung: Pustaka.

Nata, Abudin. (1997). Akhlaq Tasawuf. Jakarta: Raja Grafindo Persada. hlm 286.

Pane, Sanusi. (1955). Sejarah Indonesia, Perpustakaan Perguruan Kementerian P.P. dan K.: Djakarta,

Rahyono, FX. (2009). Kearifan Budaya Dalam Kata. Jakarta: Penerbit Wedatama Widya Sastra. 
Ridhwan. (2008). Islam Blangkon : Studi Etnografi Karakteristik Keberagamaan di Kabupaten Banyumas dan Cilacap, dalam Jurnal Istiqro', Departemen Agama Republik IndonesiaDirektorat Jenderal Pendidikan Islam dan Direktorat Pendidikan Tinggi Islam, Volume 07, Nomor 1.

Romdon. (1996). Ajaran Antologi Aliran Kebatinan. Jakarta: PT Rajagrafindo Persada cet. 1 Tahun.

Santosa, Imam Budi. (2010). Nasihat Hidup Orang Jawa. Jogjakarta: Penerbit Diva Press.

Schimmel, Annemarie. (2000). Dimensi Mistik dalam Islam. Jakarta: Pustaka Firdaus.

Sholihin, Muhammad. (2010). Ritual Kematian Islam Jaw. Yogyakarta: Narasi.

Smith, Huston. (2001). Agama-agama Manusia, Jakarta: Yayasan Obor.

Sri Mulyati. (2006). Mengenal dan Memahami Tarekat-Tarekat Muktabarah di Indonesia. Jakarta : Kencana.

Suryanegara, Mansur. (2009). Api Sejarah 1 dan 2. Bandung: Salamadani.

Uways, Abdul Halim. (1998). Fiqh Statis dan Dinamis. Bandung: Pustaka Hidayah.

Van Bruinessen, Martin. (1996). Tarekat Naqsyabandiyah di Indonesia. Bandung: Mizan

Yatim, Badri. (2001). Sejarah Peradaban Islam. Jakarta: PT Raja Grafindo. 